\title{
Frequency and antimicrobial behaviour of thermophilic Campylobacter species isolated from Ecuadorian backyard chickens ${ }^{\#}$
}

\author{
Frecuencia y comportamiento frente a antimicrobianos de especies termófilas \\ de Campylobacter aisladas de pollos de traspatio en Ecuador
}

\author{
S Ochoa ${ }^{a}$, R J Simaluiza ${ }^{a}$, Z Toledo ${ }^{a}$, H Fernández ${ }^{b^{*}}$
}

\begin{abstract}
The prevalence and antimicrobial behaviour of Campylobacter jejuni/coli isolated from backyard chickens from Southern Ecuador were determined. This study revealed that Campylobacter sp. frequency was $41.7 \%$ with high resistance to tetracycline (94.0\%) and ciprofloxacin (88\%). C. jejuni was the most frequently isolated species $(32.5 \%)$, followed by C. coli $(9.2 \%)$ being poultry colonization by Campylobacter not region dependent. This is the first study on Campylobacter antimicrobial resistance in backyard chickens in Southern Ecuador.

Key words: Campylobacter, backyard chickens, antimicrobial resistance, Ecuador.
\end{abstract}

RESUMEN. La prevalencia y el comportamiento antimicrobiano de cepas de Campylobacter jejuni/coli aisladas de pollos de traspatio del sur de Ecuador fue determinada. Este estudio revela que la frecuencia de aislamiento de Campylobacter sp. fue de 41,7\%, observándose una alta resistencia a la tetraciclina $(94,0 \%)$ y a la ciprofloxacina $(88 \%)$. C. jejuni fue la especie más frecuente $(32,5 \%)$, seguida de C. coli $(9,2 \%)$, observándose que la colonización de las aves por Campylobacter no es dependiente de la región de origen. Este es el primer estudio acerca de la resistencia a los antimicrobianos en Campylobacter aislados de pollos de traspatio en el sur de Ecuador.

Palabras clave: Campylobacter, pollos de traspatio, resistencia antimicrobina, Ecuador.

\section{INTRODUCTION}

Campylobacter species, particularly $C$. jejuni and $C$. coli, are the most frequent bacterial etiology of human gastroenteritis associated with foodborne diseases worldwide (Humphrey et al 2007, Whiley et al 2013, WHO 2013).

Acquisition of Campylobacter infections occurs through consumption of contaminated food, mainly of poultry origin, water and unpasteurized milk as well as through direct contact with animals and fowls or their faeces (Humphrey et al 2007, Fernández 2011, Whiley et al 2013, WHO 2013).

In South American and other developing countries, Campylobacter infections occur most frequently in children (Fernández 2011). Few data exist regarding the frequency of Campylobacter species in children with diarrhoea in Ecuador where these bacteria have been isolated between 10 and 23\% (Guderian et al 1987, Vasco et al 2014).

In high income countries, 58 to $76 \%$ of human cases of campylobacteriosis could be attributed to poultry sources (Mullner et al 2009, Batz et al 2011). However, in developing countries, probably due to epidemiological

\footnotetext{
Accepted: 25.02.2016.

aDepartamento de Ciencias de la Salud, Sección Genética Humana, Microbiología y Bioquímica Clínica, Universidad Técnica Particular de Loja, Loja, Ecuador.

bInstituto de Microbiología Clínica, Facultad de Medicina, Universidad Austral de Chile, Valdivia, Chile.

\#This work was supported by Project PRO_CCNN_863 UTPL 98739155.

*Corresponding author: H Fernández; hfernand@uach.cl
}

data gaps, the possible risk pathways for Campylobacter infection via poultry sources are unknown or not well outlined and understood.

Small backyard poultry flocks are popular in Southern Ecuador (Vilcabamba, Loja and Zamora cities) as an economical subsistence way and also as protein source; however there is no epidemiological information about Campylobacter in this kind of fowl in this region. For these reasons, the aim of this study was to determine the prevalence and the antimicrobial behaviour of thermophilic Campylobacter species isolated from domestic backyard chickens in Southern Ecuador.

\section{MATERIAL AND METHODS}

Cloacal swabs were randomly collected from a total of 120 chickens, corresponding 41 to birds from Vilcabamba (4 to 12 birds from 6 backyards), 32 from Loja (5 to 11 birds from 5 backyards) and 47 from Zamora regions (all the birds from the same backyard). The birds were maintained in inadequate environmental cleanliness conditions and in contact with other animal species known as reservoirs for Campylobacter like pigs, dogs, cats, sparrows and other free living birds. The cloacal samples collected were seeded into the semisolid TEM transport-enrichment medium described by Fernández (1992) consisting of (formule/L) Brucella broth $28 \mathrm{~g}$, agar $1.5 \mathrm{~g}$, sodium metabisulphite $0.5 \mathrm{~g}$, ferrous sulphate $0.5 \mathrm{~g}$, sodium pyruvate $0.5 \mathrm{~g}$, trimethoprim $10 \mathrm{mg}$, rifampicin $15 \mathrm{mg}$, colistin 10,000 IU, amphotericine 10 $\mathrm{mg}$ and defibrinated horse blood $30 \mathrm{~mL}$, and transported to the laboratory. Following an enrichment period of 24 
$\mathrm{h}$ at $42{ }^{\circ} \mathrm{C}$ under microaerobic conditions obtained using generator envelopes (Oxoid®), aliquots of each sample were seeded onto Butzler medium plates that were incubated for $48 \mathrm{~h}$ under the same conditions described above. Suspected colonies were identified morphologically (Gram stain), biochemically (oxidase, catalase, sensitivity to nalidixic acid and cephalotin, hippurate and indoxylacetate hydrolisis) and confirmed by the multiplex PCR test proposed by Yamazaki-Matsune et al (2007). In brief, after extraction of genomic DNA, $5 \mu \mathrm{L}$ of template DNA were added to a mixture containing $2 \mu \mathrm{M}$ of each primer and $25 \mu \mathrm{L}$ of $2 x$ Multiplex PCR Master Mix (QIAGEN, USA) adjusting final volume to $50 \mu \mathrm{L}$ with RNase free $\mathrm{H}_{2} \mathrm{O}$. DNA amplification was performed in thermocycler (Eppendorf) using the following cycling conditions: one cycle of initial denaturation at $95^{\circ} \mathrm{C}$ for $15 \mathrm{~min}$, followed by 25 cycles of denaturation at $95^{\circ} \mathrm{C}$ for $0.5 \mathrm{~min}$; annealing was done at $58^{\circ} \mathrm{C}$ for $1.5 \mathrm{~min}$ and extension at $72{ }^{\circ} \mathrm{C}$ for 1 min, ending with a final extension time at $72^{\circ} \mathrm{C}$ for $7 \mathrm{~min}$. Reaction mixtures were analyzed by gel electrophoresis $(3 \% \mathrm{w} / \mathrm{v}$ agarose) stained with ethidium bromide and visualised under UV transilluminator.

Susceptibility to ampicillin, amoxicillin/clavulanic acid, erythromycin, tetracycline, ciprofloxacin and gentamycin was determined by the disk diffusion method following the 2014 recommendations of The European Committee on Antimicrobial Susceptibility TestingEUCAST and the Committee for the Antibiogram of the French Society of Microbiology (Société Française de Microbiologie 2014).

Data were analysed by means of the R Statistical Computing Package (Vienna, Austria, 2005) using Fisher's exact two-tailed test with a significance level of $5 \%$.

\section{RESULTS AND DISCUSSION}

The results obtained are shown in table 1. From the 120 chickens studied, 50 (41.7\%) harbored thermophilic Campylobacter species being $C$. jejuni the most frequently isolated (39/120, 32.5\%) followed by C. coli $(11 / 120,9.2 \%)$.

With regard to the frequency for each location, the lowest isolation frequency was obtained from chickens samples collected in Loja city (37.5\%). However, the observed differences among the three groups of chickens were not statistically significant $(\mathrm{P}>0.005)$.

Table 2 shows that the isolated strains showed very high resistant frequencies to tetracycline $(94.0 \%$; C. jejuni $94.9 \%$, C. coli $91.0 \%)$ and ciprofloxacin $(88.0 \%$; C. jejuni $84.6 \%$, C. coli $100 \%)$. Resistance to ampicillin was observed in 12 strains $(24.0 \%$; C. jejuni $15.4 \%$, C. coli $54.5 \%)$. All the strains were susceptible to erythromycin, gentamycin and amoxicillin/clavulanic acid. Multi-resistance (resistance to three antimicrobials) was found in $12(24 \%)$ strains, the same that were resistant to ampicillin. Multi-resistance was most frequent amongst $C$. coli (7/11 strains, $63.6 \%)$ than in C. jejuni (4/11 strains, $36.4 \%$ ). All the ampicillin resistant strains were susceptible to amoxicillin/clavulanic acid.

The prevalence of the thermotolerant species of Campylobacter found in this study $(41.7 \%)$ was higher than the prevalence reported in Southern Chile (25.7\%) by Fernández and Torres (2000) but lower to that informed in New Zealand, where $86 \%$ of flocks tested positive with a Campylobacter isolation rate of $57.7 \%$ (Anderson et al 2012). However, in agreement with the results of these authors, our isolation rate of $C$. jejuni was higher than the rate obtained for $C$. coli. This was observed in the three groups of chicken studied and seems to be a fact regularly observed in different kinds of samples, at least in Latin American countries (Fernández 2011). Similar results were recently obtained studying chicken livers for human consumption in Southern Ecuador (Simaluiza et al 2015).

Surprisingly, we found a remarkable high resistance rate to tetracycline (94.0\%) and to ciprofloxacin (88.0\%). Previously, high resistance levels were also found in Campylobacter strains isolated from chicken livers disposed for human consumption in this same region (Simaluiza et al 2015). However we could not obtain information from the owners about the use of antibiotics, we believe that as occurs in other places of the developing world, this probably reflects an overuse of these antibiotics in backyard chickens in this region, something that could represent an epidemiological problem with implications for treatment in human beings (WHO 2013, Whitehead and Roberts 2014). This is particularly important in backyard chickens because i) exposure of children to infected backyard poultry may represent another route of transmission for

Table 1. Occurrence of Campylobacter species among backyard chickens from three locations of Southern Ecuador.

Prevalencia de especies de Campylobacter en pollos de traspatio de tres localidades del sur de Ecuador.

\begin{tabular}{lcccc}
\hline Location of Origin & $\begin{array}{c}\text { Number of } \\
\text { samples }\end{array}$ & $\begin{array}{c}\text { Campylobacter positive } \\
\mathrm{N}^{\circ} \%\end{array}$ & $\begin{array}{c}\text { C. jejuni } \\
\mathrm{N}^{\circ} \%\end{array}$ & $\begin{array}{c}\text { C. coli } \\
\mathrm{N}^{\circ} \%\end{array}$ \\
\hline Vilcabamba & 41 & $17 / 41^{*} 41.5$ & $13 / 1776.5$ & $4 / 1723.5$ \\
Loja & 32 & $12 / 32 * 37.5$ & $10 / 1283.3$ & $2 / 1216.7$ \\
Zamora & 47 & $21 / 47 * 44.7$ & $16 / 2176.2$ & $5 / 2123.8$ \\
TOTAL & 120 & $50 / 12041.7$ & $39 / 5078.0$ & $11 / 5022.0$ \\
\hline
\end{tabular}

$* \mathrm{P}>0.005$ 
Table 2. Antimicrobial behavior of Campylobacter species isolated from backyard chickens from three locations of Southern Ecuador. Comportamiento frente a antimicrobianos de Campylobacter aislados de pollos de traspatio de tres localidades del sur de Ecuador.

\begin{tabular}{|c|c|c|c|c|c|c|}
\hline $\begin{array}{l}\text { Location of } \\
\text { Origin (n) }\end{array}$ & $\begin{array}{l}\text { Amp } \\
\text { S R }\end{array}$ & $\begin{array}{l}\text { Amo-Clav } \\
\text { S R }\end{array}$ & $\begin{array}{l}\text { Genta } \\
\text { S R }\end{array}$ & $\begin{array}{l}\text { Tet } \\
\text { S R }\end{array}$ & $\begin{array}{l}\text { Ery } \\
\text { S R }\end{array}$ & $\begin{array}{l}\text { Cip } \\
\text { S R }\end{array}$ \\
\hline $\begin{array}{l}\text { Vilcabamba } \\
\text { C. jejuni (13) }\end{array}$ & $\begin{array}{c}11 / 132 / 13 \\
(84.6 \%)(15.4 \%)\end{array}$ & $\begin{array}{c}13 / 130 \\
(100 \%)(0 \%)\end{array}$ & $\begin{array}{c}13 / 130 \\
(100 \%)(0 \%)\end{array}$ & $\begin{array}{c}013 / 13 \\
(0 \%)(100 \%)\end{array}$ & $\begin{array}{c}13 / 130 \\
(100 \%)(0 \%)\end{array}$ & $\begin{array}{c}013 / 13 \\
(0 \%)(100 \%)\end{array}$ \\
\hline C. coli (4) & $\begin{array}{c}1 / 43 / 4 \\
(25 \%)(75 \%)\end{array}$ & $\begin{array}{c}4 / 40 \\
(100 \%)(0 \%)\end{array}$ & $\begin{array}{c}4 / 40 \\
(100 \%)(0 \%)\end{array}$ & $\begin{array}{c}04 / 4 \\
(0 \%)(100 \%)\end{array}$ & $\begin{array}{c}4 / 40 \\
(100 \%)(0 \%)\end{array}$ & $\begin{array}{c}04 / 4 \\
(0 \%)(100 \%)\end{array}$ \\
\hline $\begin{array}{l}\text { Loja } \\
\text { C. jejuni (10) }\end{array}$ & $\begin{array}{c}6 / 104 / 10 \\
(60 \%)(40 \%)\end{array}$ & $\begin{array}{c}10 / 100 \\
(100 \%)(0 \%)\end{array}$ & $\begin{array}{c}10 / 100 \\
(100 \%)(0 \%)\end{array}$ & $\begin{array}{c}010 / 10 \\
(0 \%)(100 \%)\end{array}$ & $\begin{array}{c}10 / 100 \\
(100 \%)(0 \%)\end{array}$ & $\begin{array}{c}010 / 10 \\
(0 \%)(100 \%)\end{array}$ \\
\hline C. $\operatorname{coli}(2)$ & $\begin{array}{cl}1 / 2 & 1 / 2 \\
(50 \%) & (50 \%)\end{array}$ & $\begin{array}{c}2 / 20 \\
(100 \%)(0 \%)\end{array}$ & $\begin{array}{c}2 / 20 \\
(100 \%)(0 \%)\end{array}$ & $\begin{array}{c}02 / 2 \\
(0 \%)(100 \%)\end{array}$ & $\begin{array}{c}2 / 20 \\
(100 \%)(0 \%)\end{array}$ & $\begin{array}{c}02 / 2 \\
(0 \%)(100 \%)\end{array}$ \\
\hline $\begin{array}{l}\text { Zamora } \\
\text { C. jejuni (16) }\end{array}$ & $\begin{array}{c}16 / 160 \\
(100 \%)(0 \%)\end{array}$ & $\begin{array}{c}16 / 160 \\
(100 \%)(0 \%)\end{array}$ & $\begin{array}{c}16 / 160 \\
(100 \%)(0 \%)\end{array}$ & $\begin{array}{c}2 / 1614 / 16 \\
(12.5 \%)(87.5 \%)\end{array}$ & $\begin{array}{c}16 / 160 \\
(100 \%)(0 \%)\end{array}$ & $\begin{array}{c}6 / 1610 / 16 \\
(37.5 \%)(62.5 \%)\end{array}$ \\
\hline C. $\operatorname{coli}(5)$ & $\begin{array}{cl}3 / 5 & 2 / 5 \\
(60 \%) & (40 \%)\end{array}$ & $\begin{array}{c}5 / 50 \\
(100 \%)(0 \%)\end{array}$ & $\begin{array}{c}5 / 50 \\
(100 \%)(0 \%)\end{array}$ & $\begin{array}{c}1 / 54 / 5 \\
(20 \%)(80 \%)\end{array}$ & $\begin{array}{c}5 / 50 \\
(100 \%)(0 \%)\end{array}$ & $\begin{array}{c}05 / 5 \\
(0 \%)(100 \%)\end{array}$ \\
\hline $\begin{array}{l}\text { TOTAL } \\
\text { C. jejuni (39) }\end{array}$ & $\begin{array}{c}33 / 396 / 39 \\
(84.6 \%)(15.4 \%)\end{array}$ & $\begin{array}{c}39 / 390 \\
(100 \%)(0 \%)\end{array}$ & $\begin{array}{c}39 / 390 \\
(100 \%)(0 \%)\end{array}$ & $\begin{array}{c}2 / 3937 / 39 \\
(5.1 \%)(94.9 \%)\end{array}$ & $\begin{array}{c}39 / 390 \\
(100 \%)(0 \%)\end{array}$ & $\begin{array}{c}6 / 3933 / 39 \\
(15.4 \%)(84.6 \%)\end{array}$ \\
\hline C. coli (11) & $\begin{array}{c}5 / 116 / 11 \\
(45.5 \%)(54.5 \%)\end{array}$ & $\begin{array}{c}11 / 110 \\
(100 \%)(0 \%)\end{array}$ & $\begin{array}{c}11 / 110 \\
(100 \%)(0 \%)\end{array}$ & $\begin{array}{c}1 / 1110 / 11 \\
(9 \%)(91 \%)\end{array}$ & $\begin{array}{c}11 / 110 \\
(100 \%)(0 \%)\end{array}$ & $\begin{array}{c}011 / 11 \\
(0 \%)(100 \%)\end{array}$ \\
\hline
\end{tabular}

$\mathrm{S}=$ susceptible, $\mathrm{R}=$ resistant, $\mathrm{Amp}=$ ampicillin, Amo-Clav = amoxicillin-clavulanic acid, Genta $=$ gentamycin, Tet $=$ tetracycline, Ery $=$ erythromycin, Cip = ciprofloxacin.

Campylobacter infection (Anderson et al 2012, Whitehead and Roberts 2014, El-Tras et al 2015), on which there are not sufficient epidemiological studies and ii) there is a lack of good biosecurity and good management practices applicable to reduce the risk of infection and antimicrobial resistance levels in backyard chickens (Whitehead and Roberts 2014, El-Tras et al 2015).

All the strains were susceptible to gentamycin, erythromycin and amoxicillin-clavulanic acid but $24.0 \%$ were resistant to ampicillin. Resistance to ampicillin and other beta-lactam antibiotics has been found in Campylobacter strains isolated from humans, poultry and poultry products. Since the ampicillin resistant strains were amoxicillin/ clavulanic acid susceptible, we can infer that the resistance to ampicillin could be mediated by the production of a beta lactamase (Simaluiza et al 2015).

Multi-resistance was found in 24\% of the strains being most frequent amongst $C$. coli than in $C$. jejuni strains. It is known that $C$. coli are usually more resistant than $C$. jejuni strains. This was also found in $C$. coli isolated from chicken livers in Southern Ecuador (Simaluiza et al 2015).

According to the results, antimicrobial resistance to tetracycline and ciprofloxacin in Campylobacter strains is a serious epidemiological problem in Southern Ecuador, whereas ampicillin resistance may be an emerging problem which could require the establishment of a laboratory surveillance program to assess its real significance. On the other hand, good biosecurity and management practices are needed to be applied to prevent the transmission of Campylobacter from poultry to children and to control antimicrobial resistance spread. Among good biosecurity and management practices are: the use of clean water, avoiding cross contamination through contact with other animals in the same farmyard as well as the implementation of basic sanitation measures in order to obtain better environmental cleanliness.

As far as we know, this is the first attempt to put in evidence the occurrence of Campylobacter species in backyard chickens in Southern Ecuador, as well their antimicrobial susceptibility and resistance profiles.

\section{ACKNOWLEDGEMENTS}

This work was supported by Project PRO_CCNN_863 UTPL 98739155. H. Fernández was supported by the Prometeo Project of the Secretariat for Higher Education, Science, Technology and Innovation of the Republic of Ecuador. 


\section{REFERENCES}

Anderson J, BJ Horn, BJ Gilpin. 2012. The Prevalence and genetic diversity of Campylobacter spp. in domestic 'backyard' poultry in Canterbury, New Zealand. Zoonoses Public Health 59, 52-60.

Batz B, S Hoffmann, G Morris. 2011. Ranking the Risks: The 10 pathogen-food combinations with the greatest burden on public health. University of Florida, Emerging Pathogens Institute. Gainesville, Florida, USA, 1-70.

El-Tras WF, HR Holt, AA Tayel, NN El-Kady. 2015. Campylobacter infections in children exposed to infected backyard poultry in Egypt. Epidemiol Infect 143, 308-315.

Fernández H. 1992. Increase of Campylobacter isolation rates using an enrichment medium. Rev Microbiol São Paulo 23, 5-7.

Fernández H, N Torres. 2000. Occurrence of Campylobacter jejuni and Campylobacter coli in three groups of hens of different geographic origin in Southern Chile. Arch Med Vet 32, 241-244.

Fernández H. 2011. Campylobacter and campylobacteriosis: a view from South America. Rev Peruana Med Exp Salud Pública 28, 121-127.

Guderian R, G Ordónez, R Bossano. 1987. Acute diarrhea associated with Canpylobacter and other pathogens in Quito, Ecuador. B Ofic Sanit Panam 102, 333-339.

Humphrey T, S O'Brien, M Madsen. 2007. Campylobacters as zoonotic pathogens: A food production perspective. Int J Food Microbiol 117, 237-257.

Mullner P, SEF Spencer, D Wilson, G Jones, AD Noble, AC Midwinter, JM Collins-Emerson, P Carter, S Hathaway, NP French. 2009.
Assigning the source of human campylobacteriosis in New Zealand: a comparative genetic and epidemiological approach. Infect Genet Evol 9, 1311-1319.

Simaluiza RJ, Z Toledo, S Ochoa, H Fernández. 2015. Resistance of Campylobacter jejuni and Campylobacter coli in chicken livers used for human consumption in Ecuador. J Anim Vet Adv 14, 6-9.

Société Française de Microbiologie. 2014. Comité de l'AntibiogrammeRecommandations 2014. Société Française de Microbiologie, Paris, France, Pp 1-115.

Vasco G, G Trueba, R Atherton, M Calvopiña, W Cevallos, T Andrade, M Eguiguren, JN Eisenberg. 2014. Identifying etiological agents causing diarrhea in low income Ecuadorian communities. Am J Trop Med Hyg 91, 563-569.

Whiley H, B van den Akker, S Giglio, R. Bentham 2013. The role of environmental reservoirs in human campylobacteriosis. Int $J$ of Environ Res Public Hlth 10, 5886-5907.

Whitehead ML, V Roberts. 2014. Backyard poultry: legislation, zoonoses and disease prevention. J Small Anim Pract 55, 487-496.

WHO, World Health Organization. 2013. The global view of campylobacteriosis. Report of an expert consultation. WHO Document Production Services, Geneva, Switzerland.

Yamazaki-Matsune W, M Taguchi, K Seto, R Kawahara, K Kawatsu, Y Kumeda, M Kitazato, M Nukina, N Misawa, T Tsukamoto. 2007. Development of a multiplex PCR assay for identification of Campylobacter coli, Campylobacter fetus, Campylobacter hyointestinalis subsp. hyointestinalis, Campylobacter jejuni, Campylobacter lari and Campylobacter upsaliensis. J Med Microbiol 56, 1467-1473. 